\title{
THE STATUS AND INTERPRETATION OF JUBILEES IN 4Q390*
}

\author{
Todd R. Hanneken
}

The study of the book of Jubilees connects several areas of scholarship on Jewish thought and literature in antiquity. The Dead Sea Scrolls cast light on our understanding of Ethiopic Jubilees, and Ethiopic Jubilees casts light on our understanding of the Scrolls. Jubilees witnesses to the growing authority of the Pentateuch, and the ongoing pluriformity of texts. Jubilees can be studied as interpretation, and also as a source for interpretation. This contribution addresses the authority of Jubilees as reflected in the way it is used in 4Q390. Parallels between Jubilees and 4 Q390 have long been noted. Careful examination of the parallels indicates that $4 \mathrm{Q} 390$ interprets Jubilees as Scripture. ${ }^{1}$

The two parts of this essay treat two major foundations of this claim. The first is the way $4 \mathrm{Q} 390$ continuously adopts language and themes from Jubilees. The second is the way $4 \mathrm{Q} 390$ wrestles with the plain sense of the text to fit a different set of beliefs. This creative adaptation does not negate the claim that Jubilees was used as authoritative literature, but rather strengthens it. One measure of a text's authoritativeness is the attention paid to adapting it to fit new and different meanings. ${ }^{2}$ This example from $4 \mathrm{Q} 390$ has broader implications. It adds to the evidence challenging the use of the category "biblical" in the study of the Scrolls, especially if the category excludes Jubilees. The appreciation of $4 \mathrm{Q} 390$ as a form of scriptural interpretation in turn casts light on our understanding of scriptural interpretation in general.

* We are all indebted to James VanderKam for his contributions to these questions, and particularly the connections between them. I am pleased to offer this study in his honor. I am also grateful to Alex Jassen, Michael Segal, Atar Livneh, and others for suggestions, comments, and discussion of the topics addressed in this paper.

1 In order to conform to editorial standards, titles of non-canonical books are distinguished from those of canonical works by italics, and the word "Scripture" is capitalized. It should be clear, however, that these modern conventions are not indicative of the centuries before the Common Era.

2 John Barton, "The Significance of a Fixed Canon of the Hebrew Bible," in Hebrew Bible / Old Testament: The History of Its Interpretation, vol. 1 (ed. Magne Sæbø; Göttingen: Vandenhoeck \& Ruprecht, 1996), 67-83, here 78. 
The present argument does not require a firm stance on the issues of relationship to other fragments, title, chronology, or date. It is legitimate to focus on $4 \mathrm{Q} 390$ as a unit of text without committing to any one of the numerous possible ways of characterizing the relationship between 4Q390 and other fragments labeled "Apocryphon of Jeremiah." Similarly, referring to the text by number aids clarity in comparing the text to Jubilees, an address to Moses, without denying that a similar revelation could have been addressed to Jeremiah. ${ }^{3}$ The chronology proposed by 4Q390 involves some complexity beyond the scope of the present essay, but it warrants a brief discussion in that all of the likely possibilities support a date of composition of 4Q390 much later than that of Jubilees. The "historical apocalypse" in Jubilees 23 corresponds with the events described in 1 Maccabees, perhaps up through the retreat of Bacchides in 159 B.C.E., but there is strikingly no trace of the high-priesthood of Jonathan starting in 152. Even the latest possible date of composition before the oldest copy, dated by J. T. Milik to the second half of the second century, would still leave plenty of time before 4Q390. While Jubilees predicts an eschatological restoration (such as it is) in the same generation as the Maccabean revolt, 4Q390 allows for 140 years following the revolt, or at least seventy years. ${ }^{4}$ Eschatological chronologies are usually revised to "correct" unfulfilled predictions and still keep the promise in the

3 In an early study Devorah Dimant called 4Q390 "Pseudo-Moses" and subsequently concluded that $4 \mathrm{Q} 390$ is part of a larger composition addressed to Jeremiah. Cana Werman defends Dimant's earlier judgment, that $4 \mathrm{Q} 390$ is an independent work addressed to Moses. See Devorah Dimant, "New Light from Qumran on the Jewish Pseudepigrapha-4Q390," in The Madrid Qumran Congress: Proceedings of the International Congress on the Dead Sea Scrolls, Madrid 18-21 March, 1991 (ed. Julio Trebolle Barrera and Luis Vegas Montaner; STDJ 11; Leiden: Brill, 1992), 405-48, here 408; D. Dimant, DJD 30:3; and Cana Werman, "Epochs and End-Time: The 490-Year Scheme in Second Temple Literature," DSD 13 (2006): 229-55, here 243-49.

${ }^{4}$ Hanan Eshel favors the interpretation that 4 Q390 counts seventy years after the Maccabean revolt, but Eshel also notes the possibility that 140 years should be counted. See Hanan Eshel, The Dead Sea Scrolls and the Hasmonean State (Grand Rapids: Eerdmans, 2008), 26 n. 37, 131. Eshel reads the seven jubilees of the devastation of the land (4Q390 1 7-8) as starting after the seventy years of exile, but admits the problem that the devastation of the land should have started with the exile. If seven jubilees ( 343 years) preceded the revolt (seven years, 4Q390 $2 \mathrm{i} 4$ ), and the total chronology is 490 years, then 140 years remain afterwards. If this is the case, seventy of those years are mentioned in 4Q390 2 i 6 as internal strife. Explicit mention of another seventy years would have to be imagined in the unreadable second column. The paleographic dating of 4 Q390 allows for 140 years after the Maccabean revolt. Cana Werman reads the periods in the first fragment out of textual order, producing a chronology of 343 years +70 years +7 years +70 years. See Werman, "Epochs and End-Time," 244-45. 
foreseeable future. The "prediction" in 4Q390 suggests a date of composition in the first century, perhaps not long before the one preserved copy, dated from paleography by Devorah Dimant to 30-20 B.C.E. ${ }^{5}$

\section{DePENDENCE ON JUbILEES}

The first part of this essay will characterize the parallels between 4Q390 and Jubilees as sustained and direct dependence. The dependence can be seen in the persistence with which 4Q390 echoes Jubilees (even if they are not all exclusive), the similarity in themes and emphases, and the use of distinctive words and phrases. 4Q390 also contains significant parallels with the Damascus Document, which can be explained as both texts depending on Jubilees. Finally, the case for understanding 4Q390 as directly dependent on Jubilees, rather than influenced by the same milieu or a milieu influenced by Jubilees, will be reinforced by considering external evidence for the status and influence of Jubilees.

Many of the parallels between 4Q390 and Jubilees have been noted, but they have not been adequately appreciated or explained. ${ }^{6}$ It does not do justice to the relationship to include Jubilees in an indiscriminate list of parallels with other Jewish works from antiquity. If one filters the parallels suggested by Dimant to exclude much later works such as 2 Baruch, or parallels of a word or two without context, one would find that the list grows much shorter. Although the Damascus Document also merits discussion, Jubilees is dominant in frequency of parallels throughout 4Q390. Indeed, the following table shows that almost every phrase in 4Q390 could come from a parallel phrase in Jubilees, especially chapters 1 and 23. The discussion is hampered somewhat by the fact that Jubilees is preserved in its entirety only in Ethiopic, and reconstruction of the Hebrew original is by no means trivial. Yet, the dependence is not necessarily word-for-word quotation with grammatical nuances intact, although that sometimes occurs, but in paraphrased language and ideas that are evident even in translation. The table does not alter the translations by Dimant for 4 Q390 and

${ }^{5}$ Dimant argues for a much earlier date of composition. In DJD 30 she argues for the last quarter of the second century, and later suggests it could have been written around the same time as the Animal Apocalypse (164 B.C.E.). See D. Dimant, DJD 30:11516; idem, "Israel's Subjugation to the Gentiles as an Expression of Demonic Power in Qumran Documents and Related Literature," RevQ 22 (2006): 373-88, here 388.

6 Dimant, "New Light from Qumran," 437-439; idem, DJD 30:102-103, 238-243, 246-249. 
James VanderKam for Jubilees, even when the same Hebrew idiom likely underlies different expressions in English. ${ }^{7}$ Significant portions of Jubilees preserved in the Scrolls are also provided (excluding cases where the Hebrew reconstructed by Milik and VanderKam matches 4Q390). The left column gives 4Q390 in its entirety, other than some stray words at the end, while the right column selects parallels and echoes from Jubilees. Parenthetical comments are italicized, and major differences are in bold face.

Excerpts from Jubilees (VanderKam)

Frg. 1 , line 2 [and ]be[fore me and a]gain I shall [deliver them ]into the hand of the sons of Aar[on ] seventy years [ ]

${ }^{3}$ And the sons of Aaron will rule over them, and they will not walk [in ]my[ wa]ys,

which I command you so that ${ }^{4}$ you may warn (תעיד) them.

And they too will do what is evil in my eyes,

like all that which the Israelites had done ${ }^{5}$ in the former days of their kingdom,

except for those who will come first from the land of their captivity to build ${ }^{6}$ the Temple.

And I shall speak to them and I shall send them commandments,

I will deliver them into the control of the nations (1:13) (Other than the crisis of the 160s, Jubilees is strongly pro-priest.)

Do not deliver them into the control of the nations with the result that they rule over them lest they make them sin against you... away from every proper path (1:19-20)

For this reason I am commanding you and testifying to you so that you may testify to them $(6: 38 ; \mathrm{cf} .1: 1)$

all that was on the earth had acted wickedly before his eyes $(5: 3)$

(1:11 seems to refer to the pre-exilic period)

(Other than Levi, Jubilees never singles out a group within Israel for elite status.)

I will give you the... commandments which I have written so that you may teach them. (1:1) 
Table (cont.)

4Q390 (Dimant)

and they will understand everything which ${ }^{7}$ they and their fathers had abandoned.

And from (the time) when that generation comes to an end, in the seventh jubilee ${ }^{8}$ of the devastation of the land,

they will forget statute and festival and Sabbath and covenant.

And they will violate everything and they will do ${ }^{9}$ what is evil in my eyes.

Therefore I shall hide my face from them and deliver them into the hands of their enemies, והסתרתי פני מהמה ונתתים ביד איביהם

and [I] shall deliver [them up] ${ }^{10}$ to the sword.

But I shall leave among them refugees (פליטים),

$s[0]$ that $[t]$ he $[y]$ should not be an[nihi]lated in my wrath [ and] when [my ] fa[ce ]is hidden ${ }^{11}$ from them.

And the Angels of Mas $[t e]$ mot will rule over them,
Excerpts from Jubilees (VanderKam)

They will not listen until they acknowledge their sins and the sins of their ancestors.

$(1: 22)$

they abandoned my statutes, my commandments $(1: 10 ; 23: 26)$

(Although the counting of time with jubilees is fundamental and distinctive to Jubilees, Jubilees never fixes sin or restoration to a predetermined time.)

They will forget all my law, all my commandments, and all my verdicts. They will err (4Q216: [ושכ], forget) regarding the beginning of the month, the sabbath, the festival, the jubilee, and the decree. (1:14, cf. $1: 10 ; 6: 37 ; 23: 19$ )

They will abrogate everything and will begin to do evil in my presence (literally: what is evil in my eyes, בעיני 4 in 4Q216). (1:12)

Then I will hide my face from them. I will deliver them into the control of the nations,

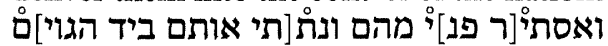
(1:13; 4Q216; “enemy" in 1:10)

He will deliver them to the sword (23:22)

(Jubilees never describes a remnant within Israel. For possible ironic allusions to a remnant, see 21:25 [all Israel is the "remnant" of Isaac] and 23:21 [those who escape are wicked])

so that they may [not] be destroyed from your presence. (1:20)

May the spirits of Mastema not rule over you and your descendants to remove you from following the Lord who is your God from now and forever. (19:28)

(Mastema is a distinctive term in Jubilees, but Mastema never rules over Israel. God alone rules Israel [15:32].) 
Table (cont.)

4Q390 (Dimant)

and[ I shall ] sp[urn them and they] will return ${ }^{12}$ to do [wh] at is evil

in [ my ] eyes, and they will walk in the will[fulness of their heart ]

Frg. 2 Col. i, line 2 [and my ]house[ and my altar and th]e Holy of Ho[lies ] ${ }^{3}$ so it was done [ ]

for these things will befall them[ ]

and [ there ] will be ${ }^{4}$ the rule of Belial over them

so as to deliver them to the sword

for a week of years[ and ]in that jubilee

they will be ${ }^{5}$ violating all my statues and all my commandments which I shall have commanded th[em and

sent in the ha]nd of my servants, the prophets.

${ }^{6}$ And [ $t$ ]he[y ]will be[gi]n to quarrel among themselves

for seventy years,

from the day of the violation of the [oath and the ] covenant which they will have violated.
Excerpts from Jubilees (VanderKam)

Those who escape will not turn from their wickedness to the right way (23:21)

following their eyes and their hearts (20:4)

They will defile the holy of holies with the impure corruption of their contamination. $(23: 21)$

So it will be that when all of these things befall them (1:6)

May the spirit of Belial not rule over them (1:20)

He will deliver them to the sword (23:22)

(see above; Jubilees never fixes sin or restoration to a predetermined time)

For they will forget all my commandmentseverything that I command them ... they abandoned my statutes, my commandments $(1: 9,10)$

I will send witnesses to them so that I may testify to them (1:12, in context the witnesses are prophets, but prophets are not lawgivers in Jubilees. See 4Q390 16 || 4Q216 II 12,

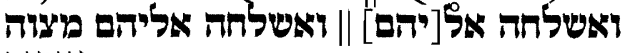
עים (ערים)

One group will struggle with another... regarding the law and the covenant. (23:19)

(see above; Jubilees never fixes sin or restoration to a predetermined time)

a covenant-accompanied by an oath-with the Israelites during this month (6:11) 
Table (cont.)

4Q390 (Dimant)

So I shall deliver them ${ }^{7}$ [into the hand of the An] gels of Mastemot, and they will rule over them.

And they will not know and they will not understand

that I was angry with them because of their trespass, ${ }^{8}$ [by which they will have for]saken me,

and will have done what is evil in my eyes, and what I did not want they will have chosen:

to pursue wealth and gain (בצע) ${ }^{9}$ [and violence, ea]ch robbing that which belongs to his neigh[b]our, and oppressing each other. They will defile my Temple,

${ }^{10}$ [they will profane my sabbaths,] they will for [ge] $t$ my[ fes] tivals,

and with fo[reign]ers [t]he[y ]will profane their offspr[ing].

Their priests will commit violence ${ }^{11}[$ ] [ ] and the ${ }^{12}$ [ ] their sons

Frg. 2 Col. ii [very fragmentary]
Excerpts from Jubilees (VanderKam)

I will deliver them into the control of the nations... with the result that they rule over them. $(1: 13,19 ; 23: 22-23)$

They will recognize that I have been more faithful than they in all their judgments and in all their actions. They will recognize that I have indeed been with them. (1:6) They will know that the Lord is one who executes judgment but shows kindness to hundreds and thousands and to all who love him. (23:31)

Then there will be great anger from the Lord against the Israelites because they neglected his covenant, departed...provoked... blasphemed...did not perform. (15:34) (see above, 4Q390 1 8-9)

for (the purpose of) cheating and through wealth so that one takes everything that belongs to another.... They will defile the holy of holies (23:21)

(see above, 4Q390 18)

The man who has defiled his daughter [with intermarriage] within all of Israel is to be eradicated because he has given one of his descendants to Molech and has sinned by defiling them... defile the Lord's sanctuary and ... profane his holy name. $(30: 10,15)$ much blood is shed on the earth by each group (23:20) 
Not all of the parallels match the idiom perfectly, and the parallel is not always exclusive. That is, in some cases $4 \mathrm{Q} 390$ could just as easily have taken the phrase from Ezekiel, Psalms, Deuteronomy, or some other authoritative work, just as Jubilees itself presumably did. However, no such source recurs in $4 \mathrm{Q} 390$ with as much context or with the same frequency as Jubilees. This is not to say 4 Q 390 interprets Jubilees and not other sources. Rather, 4Q390 interprets Jubilees among other sources in a process of mutual illumination. It should also be noted that the parallels are not sequential. 4Q390 is not a continuous reworking of Jubilees. Rather, the language and ideas are thoroughly mixed around in the mind of an author producing a new text. The fact that the language and themes are so internalized, not recycled in a linear, perfunctory way, supports the claim that Jubilees was received and used as authoritative Scripture. 4 Q390 does not interpret only Jubilees, it interprets Scripture, among which Jubilees is integral and key.

The most interesting parallels go beyond a distinctive word or phrase, to a major theme or idea. For example, 4Q390 1 3-4 echoes a major theme in Jubilees, the theme of testimony and warning, as discussed by James Kugel. ${ }^{8}$

... which I command you so that ${ }^{4}$ you may warn (תעיד, testify to) them. (4Q390 1 3-4)

For this reason I am commanding you and testifying to you so that you may testify to them. (Jub. 6:38; cf. 1:1)

The terms "testify" and "testimony" appear thirty-eight times in VanderKam's translation. It is clear from the Qumran fragments that the underlying Hebrew uses the same root as תעיד in 4Q390. ${ }^{9}$ A similar notion of warning appears in Ezekiel 3, but with a different verb, להזהיר.

Also, 4Q390 twice mentions forgetting festivals.

...they will forget statute and festival and Sabbath and covenant. (4Q390 18$)$

... [they will profane my sabbaths,] they will for[ge]t my[ fes]tivals... (4Q390 2 i 10)

They will forget all my law, all my commandments, and all my verdicts. They will err (4Q216: [ושכ]י, forget) regarding the beginning of the

${ }^{8}$ James L. Kugel, “The Jubilees Apocalypse," DSD 1 (1994): 322-37, here 328-31.

9 תעודה 4Q 4Q216 II 5; IV 4; VII 17. 
month, the sabbath, the festival, the jubilee, and the decree. (Jub. 1:14, cf. $1: 10 ; 6: 37 ; 23: 19$ )

Forgetting commandments is ubiquitous, but Jubilees is at the forefront of the explicit argument that the 364-day calendar is a legal requirement of the covenant, and that celebrating a festival on the wrong day is as bad as not celebrating the festival at all. In this case it may be possible that 4Q390 depends on another text that in turn depends on Jubilees or the same calendrical crisis. Even here it can be said, as developed below, that among the texts known to be authoritative based on the evidence found at Qumran, none is more likely the source of this idea than Jubilees.

Another distinctive idea is the connection between intermarriage and defiling the sanctuary, specifically through the interpretation of "giving offspring to Molech" in Leviticus as intermarriage. Although Jubilees is distinctive in persistently and emphatically condemning exogamy, it hardly stands alone in the inclusion of this general idea. A slightly more specific claim that foreigners and sexual relations with foreigners are defiling could come from Ezek 23:30 or Ezra 9:11, and perhaps Jubilees was partially influenced by these verses. However, the central argument for Jubilees is the interpretation of Leviticus.

I myself will set my face against them, and will cut them off from the people, because they have given of their offspring (מיזוז) to Molech,

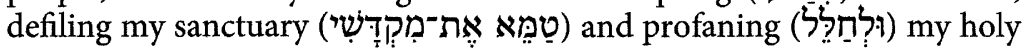
name. (Leviticus 20:3, see also 18:21)

Jubilees also drew from the context of illicit unions in Lev 21:15, where

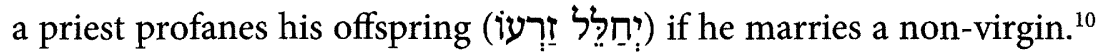
The main innovation in Jubilees is to understand "giving offspring to Molech" as intermarrying with foreigners, and thus concluding that intermarriage defiles the sanctuary. ${ }^{11}$

${ }_{10}$ Ezekiel 23:37-39 would appear to support the modern interpretation that immolating children is what defiles the sanctuary. Perhaps, if this passage was also in mind, the author of Jubilees understood "causing children to pass over to idols for food" as "giving children in marriage to idolaters for destruction."

11 A similar interpretation, as a prohibition against impregnating a foreign woman, appears in rabbinic sources, $m$. Meg. 4:9, b. Meg. 25a. James L. Kugel, "On the Interpolations in the Book of Jubilees," RevQ 24 (2009): 215-272, here 268. Géza Vermès, "Leviticus 18:21 in Ancient Jewish Bible Exegesis," in Studies in Aggadah, Targum and Jewish Liturgy in Memory of Joseph Heinemann (ed. Jakob J. Petuchowski and Ezra Fleischer; Jerusalem: Magnes, 1981), 108-124. 
The man who has defiled his daughter [with intermarriage] within all of Israel is to be eradicated because he has given one of his descendants to Molech and has sinned by defiling them.... defile the Lord's sanctuary and...p profane his holy name. (Jub. 30:10,15)

4 Q390 not only associates defiling the sanctuary and intermarriage in the same context, it uses specific language that depends on Jubilees' interpretation of Leviticus.

They will defile my sanctuary ${ }^{12}$ (את מקדשי יטמאו), [they will profane my sabbaths,] they will for[ge]t my[ fes]tivals, and with fo[reign]ers

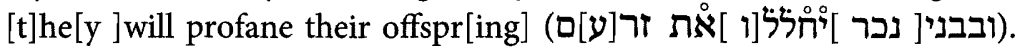
(4Q390 2 i 9-10)

The language of profaning offspring and the context of defiling the sanctuary evoke Leviticus, but "with foreigners" (partially reconstructed) reflects the interpretation found in Jubilees. The fact that 4Q390 does not mention Molech implies that it depends on the interpretation, rather than argues for the interpretation. Jubilees makes the argument more explicitly.

The broader list of sins shows that Jubilees is central, but not exclusive, as a source for $4 \mathrm{Q} 390$. The sins match emphases in Jubilees, but several could have been culled from the book of Ezekiel as a whole. ${ }^{13}$ Ezekiel 23:37-39 in particular may be on the interpretive horizon, since it associates immolating children (perhaps understood as intermarriage) with profaning the Sabbath as well as defiling the sanctuary, as in 4Q390 (reconstructed). Jubilees is an essential ingredient in 4 Q390 for forgetting festivals, and the interpretation of intermarriage. Yet, the point is not that $4 \mathrm{Q} 390$ interprets Jubilees and not Leviticus or Ezekiel. The point is that 4Q390 uses Jubilees as the key for understanding Leviticus and Ezekiel. 4Q390 accepts without further argument the meaning of Leviticus as proposed by Jubilees, and the major lessons of Ezekiel as emphasized (and supplemented) by Jubilees. As the next section will explore further, the use of Jubilees in 4Q390 does not distinguish it from Scripture, but rather places it in the category

12 Dimant translates "Temple."

13 For example, both of the words "wealth" (הון) and "cheating" (בצע) are found in Ezekiel, but not in proximity, as they are in Jub. 23:21 (Hebrew not preserved). The pair is not as generic as it may first appear. Besides 4Q390, it appears only in sectarian literature, which also could have been influenced by Jubilees. See below for the probability that $4 \mathrm{Q} 390$ shared a common influence with, but was not influenced by, the sectarian literature. 
of Scripture, a category in which any member can be taken as the key to understanding any other member.

Some of the more obvious parallels indicate dependence, but not necessarily direct dependence. Jubilees is original in its use of the term "Mastema" for a cosmic figure, and "jubilee" for a period of history, although the words already appeared in Hosea and Leviticus, respectively. As I have argued elsewhere, Jubilees does not adopt Mastema as a synonym for Satan, but introduces the term to discuss a figure that resembles Satan at first glance, but subverts the typical function of that figure. ${ }^{14}$ The originality of the use of the term in Jubilees is confirmed by empirical evidence, as other attestations of the term Mastema appear in texts that certainly or probably post-date Jubilees. ${ }^{15}$ 4Q390 depends on the sense of the term "Mastema" as a cosmic figure in fragment 1 line 11 and fragment 2 line 7, "the Angels of Mastemot." The most obvious adaptation is that $4 \mathrm{Q} 390$ uses a construct double plural, perhaps reflecting the belief that the present world is dominated by a multitude of evil cosmic forces, contrary to the simple sense of Jubilees, as discussed in the following section. ${ }^{16}$ It may indeed be the case that משטמות is a common noun in this phrase, better translated "Angels of Loathings." ${ }^{17}$ But even so, it is part of title that refers to a particular class of cosmic beings. The translation "Angels of Mastemot" is preferable because it preserves the allusiveness of the noun. ${ }^{18}$ Although this use of the term can be traced to Jubilees, it does not follow from this point alone that $4 \mathrm{Q} 390$ uses Jubilees directly, since the term becomes reasonably common in the decades following the composition of Jubilees.

14 Todd R. Hanneken, "The Book of Jubilees Among the Apocalypses" (Ph.D. diss., University of Notre Dame, 2008), 287-88. Online: http://etd.nd.edu/ETD-db/theses/ available/etd-06302008-112007.

15 Kugel ("Interpolations in Jubilees," 221) also rejects the possibility that Mastema (as a name) in Jubilees depends on earlier sources.

16 There is also an innovation in the term "angel," whereas Jubilees uses the title "prince" and mentions Mastema in the heavenly court without explicitly calling Mastema an angel.

17 So Kugel, "Interpolations in Jubilees," 221 n. 11. Kugel suggests lowercase letters, but context supports capitalization for a title of a specific class of cosmic beings.

${ }^{18}$ Indeed, even in Jubilees one could question whether Mastema is necessarily a proper noun. The point here is not so much whether it is a proper or common noun, but whether it refers to a cosmic entity. In Hos 9:7-8 it is a human attribute; in Jubilees and following texts it becomes cosmic, often associated with Belial. See further Hanneken, "The Book of Jubilees Among the Apocalypses," 286-89; James C. VanderKam, Textual and Historical Studies in the Book of Jubilees (Missoula, Mont.: Scholars Press, 1977), 266. 
Similarly, counting history in jubilee periods is a major and original feature of Jubilees. Leviticus uses the term for a year of release and return, not a period of history. Jubilees is not the first heptadic chronology, but it is the first to relate history in jubilee periods. ${ }^{19}$ Again, this originality is more than an accident of preservation. The term "jubilee" is not only frequent in Jubilees, it is fundamental to the chronological structure of the book. Jubilees understands the exodus and conquest as release and return in the fiftieth period of history since creation, adapted from Leviticus $25 .{ }^{20} 4 \mathrm{Q} 390$ depends on the idea of a jubilee as a period of history in fragment 1 line 7 and fragment 2 line 4. Again, there is an adaptation in the usage, to be addressed in the second section.

Another formal parallel is worth mentioning, even if it alone is not distinctive. 4Q390 and Jubilees, particularly chapter 1, both follow the form of heavenly direct address in the first person (God in 4Q390 and Jubilees 1, an angel in the rest of Jubilees) to a transmitter of law and testimony in the second person.

The strong correlation between 4Q390 and Jubilees can be seen from the persistence with which 4Q390 echoes Jubilees, the shared major themes, and the overlap in distinctive formal features. Individual phrases could also have come from an older authority, but no other single text echoes as strongly through 4 Q390 as Jubilees. The closest competition for this claim is the Damascus Document. The parallels are best explained if the Damascus Document and 4Q390 made use

19 James C. VanderKam, Calendars in the Dead Sea Scrolls: Measuring Time (London: Routledge, 1998), 91-109; idem, "Studies in the Chronology of the Book of Jubilees," in From Revelation to Canon: Studies in the Hebrew Bible and Second Temple Literature (JSISup 62; Leiden: Brill, 2000), 522-44, here 522-28, translated from "Das chronologische Konzept des Jubiläenbuches," ZAW 107 (1995): 80-100. Daniel 9 is a good example of a heptadic chronology that would have been compatible with counting in jubilee periods if the idea had been known, which makes it all the more striking that it is not mentioned. 11QMelchizedek and the Testament of Levi are later than Jubilees. The Testament of Moses is also later, and raises the further question of whether the jubilee period should have been 49 years or 50 years. Even if the word 'jubilee' could have been understood as a period of history prior to the composition of Jubilees, it could still be an innovation to count the period as forty-nine years-thus adapting it to fit heptadic chronology-rather than fifty, which may have been the more obvious implication of Leviticus 25. For the claim that the jubilee period was fifty years in sources before Jubilees see Devorah Dimant, "The Biography of Enoch and the Books of Enoch," VT 33 (1983): 14-29, here 21. For an alternative explanation of Jub. 4:21, see Hanneken, "The Book of Jubilees Among the Apocalypses," 130-32.

${ }_{20}$ VanderKam, Calendars in the Dead Sea Scrolls, 102; idem, "Studies in the Chronology of the Book of Jubilees," 540-43. 
of Jubilees. One alternative possibility is that $4 \mathrm{Q} 390$ depends on the Damascus Document, but if the author held the Damascus Document as authoritative, one might expect some allusion to the Teacher of Righteousness or distinctive sectarian terminology. Most scholars recognize that 4 Q390 does not come from the sect described by the Damascus Document, even if some similarities suggest a proximity of some sort. ${ }^{21}$ It is neither possible nor necessary to rule out the probability that the interpretation of Jubilees in 4Q390 is influenced in some small way by the Damascus Document. It is unlikely that the Damascus Document depends on $4 \mathrm{Q} 390$, given the date of the oldest manuscript and other indicators of the date of composition.

It is clear enough that the Damascus Document depends on Jubilees. The most famous example is column 16, which cites Jubilees by its ancient title, "the book of the Divisions of the Times into Their Jubilees and Weeks." In the same context the Damascus Document elaborates on the distinctive themes of Mastema and the immunity from Mastema learned by Abraham, namely circumcision as the marker of protection from demons, and the related protection of studying the Law of Moses. Also, column 2 of the Damascus Document seems to depend on Jubilees 2 for the idea that God elected the chosen people from the beginning of creation. The claim in column 10 that knowledge departs at age sixty fits Jubilees 23 particularly well. There is one scholar who claims that the Damascus Document does not depend on Jubilees. It is certainly significant that this scholar is the DJD editor of 4Q390, Devorah Dimant. ${ }^{22}$ Dimant's understanding of “dependence" is unusually narrow. Consequently, one should take it with a grain of salt that Dimant does not identify 4 Q390 as particularly dependent on Jubilees. Dimant does discuss the parallels between 4 Q390 and the sectarian literature, and she suggests a little too vaguely, "it may

${ }^{21}$ D. Dimant, DJD 30:112; idem, "Israel's Subjugation." The exception is Werman, but she defines the category "Qumran community" as a broad plurality of groups that also produced the Animal Apocalypse and Jubilees. She explains the lack of reference to the sect in Jubilees and $4 \mathrm{Q} 390$ as the result of being addressed to an outside audience. See Werman, "Epochs and End-Time." See also Cana Werman, "The Book of Jubilees and the Qumran Community," Meghillot 2 (2004): 37-55 [Hebrew]; idem, "The Eschaton in Second Temple Literature," Tarbiz 72 (2003): 37-57 [Hebrew].

22 Devorah Dimant, "Two 'Scientific' Fictions: The So-Called Book of Noah and the Alleged Quotation of Jubilees in CD 16:3-4," in Studies in the Hebrew Bible, Qumran, and the Septuagint: Essays Presented to Eugene Ulrich on the Occasion of his SixtyFifth Birthday (ed. Peter W. Flint, et al.; VTSup 101; Leiden: Brill, 2003), 230-49, here $242-48$. 
be assumed that both drew on the same tradition or on a biblicizing composition. ${ }^{23}$ The evidence examined in this essay suggests that the biblicizing composition in question is none other than the book of Jubilees.

More can be said in support of the suggestion that 4 Q390 depends directly on Jubilees, and not the same intellectual milieu, or a hypothetical intermediate document. Copious evidence outside 4Q390 indicates that Jubilees was highly authoritative at Qumran, and additional evidence suggests that some of that authority extended to larger, not strictly sectarian, circles. First, the number of copies of Jubilees found at Qumran is surpassed only by Psalms, Deuteronomy, Isaiah, Genesis, and Exodus. ${ }^{24}$ In addition to these, numerous texts bear enough resemblance to Jubilees that they were labeled Pseudo-Jubilees (4Q225-227). Imitation and re-working may be an even greater indicator of a text's authority than additional copies. Among works not canonical in rabbinic Judaism, Jubilees also has the rare distinction of apparently being cited as Scripture (that is, 4Q228 1 i 9, כי כִ כْתוב כבי. Document, the ancient title "Divisions of the Times" also appears in $4 \mathrm{Q} 384$, a text originally grouped with $4 \mathrm{Q} 390$ but identified by Dimant as Jeremiah Apocryphon "B" rather than "C." This does not exhaust

${ }^{23}$ D. Dimant, DJD 30:103. Similarly, Tamási suggests a "Levite tradition" as the source of parallels between CD, ALD, Jubilees, and $4 \mathrm{Q} 390$. On the issue of forgetting festivals, Tamási suggests that CD and $4 \mathrm{Q} 390$ depended on "the original source of $J u b i$ lees." See Balázs Tamási, "Prophesized History of the Postexilic Period and Polemics against Priests in 4Q390 from Qumran: Levite Authorship behind the Fragments?" in With Wisdom as a Robe: Qumran and Other Jewish Studies in Honour of Ida Fröhlich (ed. Karoly Daniel Dobos and Miklos Koszeghy; Hebrew Bible Monographs 21; Sheffield: Sheffield Phoenix, 2008), 310-28, here 320, 328. A virtually identical article with the same title appeared in Henoch 31/2 (2009).

${ }^{24}$ Milik counted 15 copies of Jubilees including 4Q217, which VanderKam excluded to count 14. See James C. VanderKam, "The Jubilees Fragments from Qumran Cave 4," in The Madrid Qumran Congress: Proceedings of the International Congress on the Dead Sea Scrolls, Madrid, 18-21 March, 1991 (ed. Julio C. Trebolle Barrera and Luis Vegas Montaner; STDJ 12; Leiden: Brill, 1992), 635-48, here 640, 648. The latest counts for other Hebrew texts found at Qumran are 35-37 for Psalms, 28-30 for Deuteronomy, 21 for Isaiah, 20-21 for Genesis, and 16 for Exodus.

${ }^{25}$ Line 1 of the same fragment, partially reconstructed, uses the ancient title of the book of Jubilees, במחל][1][ن העתים]. Other language in the fragment is reminiscent of Jubilees. See VanderKam, "The Jubilees Fragments from Qumran Cave 4," 644; J. VanderKam and J. Milik, DJD 13:178; James C. VanderKam, "Authoritative Literature in the Dead Sea Scrolls," DSD 5 (1998): 382-402, here 393. 
the catalog of the influence of Jubilees among the Scrolls, which will likely grow with additional study. ${ }^{26}$

It is slightly more difficult to gauge the influence of Jubilees outside the narrow confines of the sectarian literature. Cana Werman has even argued that Jubilees itself is a sectarian composition. ${ }^{27}$ If that were the case, however, Jubilees would be the only sectarian composition preserved and used by a scribal tradition outside the sect. As VanderKam has suggested, the canonical status of Jubilees in Ethiopic Christianity likely reflects a judgment by an ancient Jewish community. ${ }^{28}$ Other Christians stopped short of treating Jubilees as canonical, but the text was at least known to a wide circle of Syriac, Greek, and Latin speaking Christians. A Hebrew copy found its way to the medieval Asaph the physician by unknown channels. ${ }^{29}$ Even if Jubilees was less authoritative in circles distant from Qumran, the circle of $4 \mathrm{Q} 390$ is not distant from Qumran, as indicated by the copy found at Qumran and other similarities discussed in the next section of this essay.

External evidence indicates that Jubilees was authoritative in the world around 4Q390, and internal evidence indicates that 4Q390 dwells on Jubilees from beginning to end, adopting language, style, and some ideas. This close and persistent use of authoritative literature brings us to the category of interpretation. The case for identifying

${ }^{26}$ Expanding on an observation made by VanderKam, Shemesh argues that 4Q265 is a rewriting of Jubilees (the connection between Leviticus 12 and Eden) and concludes that Jubilees had canonical status at Qumran. Shemesh also points to Jub. 22:16-22 as a source for 1QS 5, and to Jub. 2:29 and 50:8 as sources for the Sabbath halakha in 4Q251 113 and CD 11:1-2. See Aharon Shemesh, "4Q265 and the Authoritative Status of Jubilees at Qumran," in Enoch and the Mosaic Torah: The Evidence of Jubilees (ed. Gabriele Boccaccini and Giovanni Ibba; Grand Rapids: Eerdmans, 2009), 24760. Cf. VanderKam, "Authoritative Literature"; idem, "Questions of Canon Viewed Through the Dead Sea Scrolls," in The Canon Debate (ed. Lee Martin McDonald and James A. Sanders; Peabody, Mass.: Hendrickson, 2002), 91-109, here 106. See also Joseph M. Baumgarten, "Purification after Childbirth and the Sacred Garden in 4Q265 and Jubilees," in New Qumran Texts and Studies: Proceedings of the First Meeting of the International Organization for Qumran Studies, Paris 1992 (ed. George J. Brooke and Florentino García Martínez; Leiden: Brill, 1994), 3-10; Charlotte Hempel, "The Place of The Book of Jubilees at Qumran and Beyond," in The Dead Sea Scrolls in Their Historical Context (ed. Timothy H. Lim; Edinburgh: T\&T Clark, 2000), 187-196.

${ }^{27}$ Werman, "Jubilees and the Qumran Community," 37-55 [Hebrew]. See note 21 above.

${ }^{28}$ VanderKam, “Authoritative Literature," 400.

${ }^{29}$ For a discussion of the evidence that Asaph depends on a Hebrew copy of Jubilees (rather than a source or translation of Jubilees) see Michael Segal, The Book of Jubilees: Rewritten Bible, Redaction, Ideology and Theology (JSJSup 117; Leiden: Brill, 2007), 171-74. 
4Q390 as interpretation of Jubilees is strengthened by the tension between the simple sense of Jubilees and the use to which it is put in 4 Q390. Simply put, the authority of Jubilees for the author of 4Q390 is evident not only in the extent to which the author adopts Jubilees as it stands, but in the extent to which the author insists that the text concords with the author's own ideas, contrary to the simple sense. As John Barton has discussed, the need for interpretation is a hallmark of Scripture. ${ }^{30}$

\section{DEVIATION FROM JUBILEES}

The first major way that $4 \mathrm{Q} 390$ adapts the simple sense of Jubilees pertains to the issue of angels ruling over Israel. 4Q390 follows Jubilees three times almost verbatim for the image of angels of Mastema or Belial ruling over Israel.

And the Angels of Mas[te]mot will rule over them...(4Q390 1 11)

May the spirits of Mastema not rule over you and your descendants to remove you from following the Lord who is your God from now and forever. (Jub. 19:28, emphasis mine)

... and [ there ]will be the rule of Belial over them...(4Q390 2 i 3-4)

May the spirit of Belial not rule over them...(Jub. 1:20, emphasis mine)

So I shall deliver them [into the hand of the An]gels of Mastemot, and they will rule over them. (4Q390 2 i 6-7)

I will deliver them into the control of the nations... with the result that they rule over them. (Jub. 1:13, 19; 23:22-23, emphasis mine)

The biggest difference in the first two examples is that Jubilees has in the middle the word "not," which changes the meaning entirely. It is not simply the case that different grammatical constructions apply to different points in the narrative. Jubilees does not imply that direct rule by God is merely wishful thinking or the exception. Jubilees allows that individuals and even a whole generation can sin, but chastisement and repentance occurs between God and Israel with no angelic outsourcing. Jubilees never compromises on the principle in chapter 15 ,

[God] made spirits rule over all [the nations] in order to lead them astray from following him. But over Israel he made no angel or spirit

${ }^{30}$ Barton, "Significance of a Fixed Canon," 78. 
rule because he alone is their ruler. He will guard them and require them for himself from his angels, his spirits, and everyone, and all his powers so that he may guard them and bless them and so that they may be his and he theirs from now and forever. (Jub. 15:31-32, emphasis mine)

Jubilees 10 accounts for the existence of demons, but rather than dominating and afflicting the righteous, they are diminished and restricted to punishing the wicked Gentiles. Israelites can be in danger in as much as they may be tempted to join with Gentiles, but the righteous who study the sacred books have immunity. The absence of angelic agency is especially striking in Jubilees 23 , where one would expect angelic rule, conflict, and judgment to appear in the eschatological climax of a historical apocalypse. In fact, angels never appear in the chapter, and accusers or satans are mentioned only as being absent. Elsewhere in the book, Mastema is more a parody of an evil ruler who afflicts Israel. Mastema takes on unbecoming functions attributed to God in Genesis-Exodus, such as proposing a test that Abraham sacrifice Isaac. In each case, Mastema never claims any victory, only immediate shame. ${ }^{31}$ For example, the folly of the Egyptians is attributed to Mastema, but successful evil, such as throwing babies into the Nile, is not attributed to Mastema.

In general, Jubilees rejects the view of the world as corrupt, ruled by evil powers, and in need of radical divine intervention. 4Q390 takes the opposite view. One might expect a text like 4Q390 not to use a text with such a different tone. The fact that 4Q390 uses it anyway, and projects onto it a view of the world at odds with the simple sense, even while borrowing the same literary formulae, indicates the status of Jubilees as a received authority. This relationship is more than simply dependence on a source, as could be said of less tendentious borrowed language and even whole copies. It is the relationship of interpretation and that which requires interpretation, which partly defines the category "Scripture."

A second area in which the pessimistic view in 4 Q390 clashes with the optimistic view in Jubilees is the view of the priesthood and the temple. From the top of fragment 1 we learn that Israel is delivered into the hands of the sons of Aaron, to rule over them. The language here parallels three other instances in which Israel is handed over to or ruled over by the angels of Mastemot and Belial. The view of the

31 Todd R. Hanneken, "Angels and Demons in the Book of Jubilees and Contemporary Apocalypses," Henoch 28/2 (2006): 11-25, here 20. 
Second Temple priesthood is certainly negative, although the polemic should not be overstated. ${ }^{32}$ Similarly, the temple, though originally built by good people, becomes corrupt and seems to remain so for an extended period of time, from the top to the bottom of fragment 2 .

In Jubilees the view of the priesthood is overwhelmingly positive. The apostate priests and defiled sanctuary of the 160 s are exceptional and temporary. ${ }^{33}$ The praise of Levi spans three chapters from 30 to 32 and goes to the extreme of overkill with six arguments for the elevation of Levi. ${ }^{34}$ This is in addition to references throughout the book, such as the hierarchy of three types of angels created on the first day to mirror the hierarchy of Levites, Israel, and other nations (Jub. 2:2, $18-19 ; 15: 31 ; 30: 18)$. There is no suggestion that some Levites will be wicked. The praise of Levi without mention of Aaron fits with the emphasis on unity in Jubilees, not an anachronistic polemic between Levites and Aaronides. ${ }^{35}$ The praise of Levi is amplified with language of eternality, without eschatological reform. It is possible that an interpreter saw the positive view in Jubilees as the original plan that later became corrupted, but the simple sense of Jubilees leaves no suggestion that the teaching and cultic authority of the Levites will disintegrate. Similarly, Jubilees has a very positive view of the temple, with no indication that there would be anything wrong with it other than the crisis of the 160 s B.C.E. ${ }^{36}$

${ }^{32}$ Hanan Eshel views the priests as singled-out for condemnation, but it could be that all Israel sins under the rule of the priests. The time when Israel is ruled by priests could be a relatively neutral way of describing the Second Temple period, without implying that all sons of Aaron are inherently evil. See Hanan Eshel, Dead Sea Scrolls and the Hasmonean State, 22, 24, 26. See also Werman, "Epochs and End-Time," 248-49.

${ }^{33}$ Jubilees refers to a generation of warring and corrupt claimants to the high priesthood, "They will mention the great name but neither truly nor rightly. They will defile the holy of holies with the impure corruption of their contamination" (Jub. 23:21). This chapter emphasizes, however, that this would occur for only one generation $(J u b .23: 14,15,16,22)$ before divine punishment and human repentance would reverse the situation.

${ }^{34}$ Hanneken, "The Book of Jubilees Among the Apocalypses," 499-505.

35 The battles between priestly families that raged in the First Temple period through the early Second Temple period were not the same battles that raged in the late Second Temple period. Starting with Chronicles, the status of the Levites was established enough that one could say positive things about Levites without being anti-Aaronide or anti-Zadokite. For a different view, that 4Q390 opposes the Aaronides and therefore was written by a Levite, see Tamási, "Polemics against Priests in 4Q390," 310-28.

${ }^{36}$ Hanneken, "The Book of Jubilees Among the Apocalypses," 429-30. This is not to deny that Jubilees still imagined a more perfect, ideal functioning of the temple in the future. 
A third area concerns the unity of Israel in general. For this point it is necessary to distinguish two senses of the word "sectarian." The first sense is belonging to the particular family of sects described with distinct terminology among the Dead Sea Scrolls. The second sense is a broader quality of rejecting the unity of Israel in favor of a small group that differs from everyone else in knowledge and eschatological vindication. 4Q390 does not reflect the specific history and language of the Damascus Document, but it does reflect the broader sense of rejection of most of Israel. Besides the aforementioned disparaging of the ruling priesthood, 4Q390 first reflects the view that the righteous are exceptional:

And they too will do what is evil in my eyes, like all that which the Israelites had done in the former days of their kingdom, except for those who will come first from the land of their captivity to build the Temple. (4Q390 1 4-6)

These few are characterized by reception of commandments and understanding that distinguish them from the rest of Israel (4Q390 16). The majority persists in ignorance with no hope of return (4Q390 2 i 7). Most of Israel is given over to annihilation, while only a remnant is separated: "But I shall leave among them refugees so that they should not be annihilated in my wrath and when my face is hidden from them" (4Q390 1 10). The permanent rejection and rule by Mastema that Jubilees applied to foreign nations applies to most of Israel in 4Q390.

Jubilees frequently emphasizes the permanent election of all of Israel, from the first week of creation through eternity. Other than the elevation of Levi, no divisions within Israel are imagined. As Martha Himmelfarb observed, sin in Jubilees is not sectarian but generational. ${ }^{37}$ Indeed, more often it is personal. Jubilees might be called protosectarian in some respects. Some of the positions defended strongly in Jubilees, such as the solar calendar, went on to be rejected in the forms of Judaism that retained dominance. Jubilees also maintains the threat, at least on the issue of circumcision, that Jews can forfeit their divine protection and even their status as Jews, which could have serious sectarian implications. ${ }^{38}$ Even if the author was naive about some

${ }^{37}$ Martha Himmelfarb, A Kingdom of Priests: Ancestry and Merit in Ancient Judaism (Philadelphia: University of Pennsylvania Press, 2006), 81-83.

${ }^{38}$ In particular, $J u b .15: 26$ defines two groups (inciuded in and excluded from the covenant), and suggests that one can forfeit inclusion, "Anyone who is born, the flesh 
implications, there is no sense that most of those who claim to be Jews are not really Jews, or that a certain group of Jews who follow different legal rulings are beyond repentance. The sinners are uninformed individuals, not a sect. When language of "elect," "remnant," and "righteous plant" does occur, it strikingly refers to all of Israel, as in Jub. 21:25, where Jacob is the "remnant" of Isaac, while Esau is excluded. ${ }^{39}$ In the eschatological sequences in Jubilees 1 and 23 there is no vengeance against other parts of Israel; rather, the whole nation eventually returns. Similarly, Jubilees rejects the necessity of esoteric or elite knowledge. The heavenly tablets are revealed and made plain to all Israel at Sinai, not an elect few. The Levites have the role of teaching the commandments to the people, not hoarding secret knowledge. Again in 4Q390, similar language varies mainly with the word "not."

And they will not know and they will not understand...(4Q390 2 i 7, emphasis mine)

They will recognize that I have been more faithful than they in all their judgments and in all their actions. They will recognize that I have indeed been with them. (Jub. 1:6)

They will know that the Lord is one who executes judgment but shows kindness to hundreds and thousands and to all who love him. (Jub. 23:31)

of whose private parts has not been circumcised by the eighth day does not belong to the people of the pact...but to the people (meant for) destruction" (Jub. 15:26). Jubilees often contrasts Jews and Gentiles, and warns against Jews going in the ways of Gentiles. Thus, one who avoided or covered circumcision entirely (see 1 Macc 1:15) would be counted among the Gentiles. The controversy in Jub. 15:26 is that it seems to deny the Jewishness not only of those who reject circumcision entirely, but also those for whom it is delayed for any reason. The Mishnah would indicate that the Pharisees allowed circumcision to be slightly delayed $(m$. ̌̌abb. 19:5). It is clear that the author of Jubilees had strong opinions and knew of other opinions, but the sociological dimension-defined groups or sects within Judaism-is far from clear. It is not clear that Jubilees knew anything about the Pharisees, or thought of any group as enemies of God because they tolerated ninth-day circumcision, or would have thought of someone circumcised on the ninth day as permanently excluded from any hope of repentance. It may be the case that the author viewed boys circumcised late as temporarily unprotected from demons, or rejected adult converts, or simply had the status of Ishmael in mind more than contemporary legal debates (see Segal, The Book of Jubilees, 241-43).

${ }^{39}$ There may be an exception in Jub. 1:29, "all the elect ones of Israel," but in light of the rest of the book it is best to understand the verse as identifying the chosen people with Israel, not isolating a chosen people within Israel. 
Jubilees even rejects the view of revelation as coded such that elite wisdom is necessary to decode the true meaning. As Armin Lange has shown, Jubilees rejects revelation encoded in symbolic dreams even when it occurs in Genesis. ${ }^{40}$ Jubilees and 4Q390 share a common notion of salvific knowledge that is strictly limited to one group while all others lack knowledge and are abandoned to demonic rule and destruction. The fundamental difference is that in Jubilees the elect group is all of Israel apart from the Gentiles, but in $4 \mathrm{Q} 390$ the elect group is a sect apart from the rest of Israel.

One last example will show how the same language can be adapted to a different context to convey a significantly different meaning. $4 \mathrm{Q} 390$ draws from Jubilees for the idea of counting history in jubilee periods. Jubilee periods are indeed frequent and fundamental to the book, and particularly to its argument that the jubilee of jubilees was the release and return of Israel from Egypt. Equally striking, however, is the exception. Jubilees never mentions determined times for sin and repentance. ${ }^{41}$ All events, even divine actions, are conditional on human action. ${ }^{42}$ The basic message to humans is that they should repent, not persevere until a particular time appointed for divine intervention. Like Deuteronomy, Jubilees predicts the occurrence of sin, punishment, repentance, and restoration, but it does not present it as temporally pre-determined. $4 \mathrm{Q} 390$ adopts the idea of relating history in jubilee periods, but applies the idea to precisely the area that the book of Jubilees did not, the prediction of sin.

40 Armin Lange, "Divinatorische Träume und Apokalyptik im Jubiläenbuch," in Studies in the Book of Jubilees (ed. Matthias Albani, et al.; TSAJ 65; Tubingen: Mohr, 1997), 25-38.

${ }^{41}$ Martha Himmelfarb, “Torah, Testimony, and Heavenly Tablets: The Claim to Authority of the Book of Jubilees," in A Multiform Heritage: Studies on Early Judaism and Christianity in Honor of Robert A. Kraft (ed. Benjamin G. Wright; Scholars Press Homage Series 24; Atlanta: Scholars Press, 1999), 19-29, here 24.

${ }^{42}$ This remains true even if one accepts David Lambert's claim that the human action, in the case of Jubilees, is not repentance in the sense of turning away from sin, but recognition of human sinfulness and the need for divine transformation. However, the two options are not mutually exclusive in Jubilees, and human action precedes divine action. Returning to God and the law appears frequently in Jubilees, even in Lambert's central passage, where Israel "will return to me [God] in a fully upright manner" before God circumcises their minds (Jub. 1:23). Lambert's arguments for discounting other passages that describe repentance are not convincing (Jub. 1:15; $5: 17 ; 23: 26)$. See David Lambert, "Did Israel Believe That Redemption Awaited Its Repentance? The Case of Jubilees 1," CBQ 68 (2006): 631-50. 
And from (the time) when that generation comes to an end, in the seventh jubilee of the devastation of the land, they will forget statute and festival and Sabbath and covenant. (4Q390 $17-8$ )

[And] in that jubilee they will be violating all my statues and all my commandments... (4Q390 2 i 4-5)

4Q390 adopts the authority of Jubilees, but projects onto it a view of evil as temporally predetermined, contrary to the original sense of the source.

\section{CONCLUSION}

In conclusion, 4Q390 interprets Jubilees as Scripture. That entails relying on the authority of Jubilees by adopting its language, style, imagery and motifs. It also entails adapting the apparent meaning of the text to concord with the ideas of the interpreter. The tensions do not diminish but strengthen the case for the status of Jubilees. As Scripture, Jubilees needs to be interpreted. It can and must be understood differently as applying to different circumstances. ${ }^{43}$ As indicated by column 16 of the Damascus Document, Jubilees was received as the authoritative specification of the times of Israel's blindness. An author who accepted such a status of Jubilees was compelled to give the impression of conformity with Jubilees, even if interpretive labor was required.

${ }^{43}$ Cf. 4Q252 1 i 7-10 as a "correction" of Jub. 5:27, and other examples discussed by James C. VanderKam, "The Origins and Purposes of the Book of Jubilees," in Studies in the Book of Jubilees (ed. Matthias Albani, et al.; TSAJ 65; Tübingen: Mohr Siebeck, 1997), 3-24, here 3. 